\title{
WORK PERFORMANCE OF THE FAMILY PLANNING FIELD WORKERS IN THE REDUCTION OF TOTAL FERTILITY RATE IN SIBOLGA, NORTH SUMATERA
}

\author{
Widia Astuti Tanjung1), Heru Santosa ${ }^{2}$, Kintoko Rochadi3) \\ 1)Department of Health Policy and Administration, Universitas Sumatera Utara \\ 2)Department of Biostatistics and Population, Universitas Sumatera Utara \\ 3)Department of Health Promotion and Behavior, Universitas Sumatera Utara
}

\begin{abstract}
Background: Over the past 40 years, family planning has reduced fertility rates in developing countries, from six births per woman to about three per woman. Lower birth rates contribute to slower population growth, which enables economic development and environmental sustainability. Despite these successes, the family planning agenda remains unfinished. This study aimed to asses the work performance of the family planning field workers in the reduction of total fertility rate in Sibolga, North Sumatera.

Subjects and Method: This was a qualitative study conducted in Sibolga, North Sumatera. The study subjects were family planning field workers. The variable under study was work performance. The data were colected by in-depth interview, direct observation, and document review.

Results: The work performance of family planning field workers remained suboptimal. Work performance was monitored indirectly by social media such as group chat. There was no direct monitoring. There was discrepancy between data reported and the actual conditions. For examples, the number of family planning participants in the field was different from those reported at the family planning office. There was often a lag time of reporting. The TFR target was not achieved despite the sufficient number of personnel. The family planning field workers had low skill in family planning promotion and had a lack of discipline. They often violated the order and came late at the office.

Conclusion: The work performance of the family planning field workers is still suboptimal. There is a need to implement regular monitoring, provide skill training especially in family planning promotion, provide reward to subdistricts that achieve low TFR, and schedule family planning promotion, in order to reduce TFR.
\end{abstract}

Keywords: job performance, family planning, field worker, Total Fertility Rate.

\section{Correspondence:}

Widia Astuti Tanjung. Department of Health Policy and Administration, Universitas Sumatera Utara, Medan, North Sumatera.

Email: widiaastutitanjung@gmail.com. Mobile: 085206885075. 